TAHKIM, Jurnal Peradaban dan Hukum Islam. Vol.4 No.1 (Maret, 2021) | ISSN : 2597-7962

\title{
SEKUFU DALAM KONTEKS HUKUM KELUARGA MODERN
}

\author{
Rafida Ramelan \\ Institut Agama Islam Darussalam Ciamis \\ rafidaramelan09@gmail.com
}

\begin{abstract}
ABSTRAK
Islam memberikan perhatian yang sangat besar terhadap kesejahteraan keluarga. Dalam membentuk sebuah keluarga, sebelum terjadinya perkawinan hendaknya calon suami dan istri saling mengenal pasangannya satu sama lain. Keserasian dan keseimbangan antar pasangan sangat dibutuhkan dalam mengarungi bahtera rumah tangga. Hal ini dapat dilakukan sejak tahap peminangan, yakni saat seseorang menentukan siapa yang pantas untuk dijadikan sebagai pendamping hidupnya. Keserasian dan keseimbangan dalam Islam dikenal dengan istilah kufu' atau kafa'ah. Di era modern ini tidak jarang kita temukan problem rumah tangga yang diakibatkan adanya perbedaan yang mencolok diantara keduanya dalam berbagai hal, baik dari sisi agama, ras, status sosial, dan sebagainya. Kriteria sekufu dalam Islam pada dasarnya hanya meliputi faktor harta, keturunan, kecantikan dan agama. Namun seiring berjalannya waktu, konsep ini berkembang menjadi beberapa faktor seperti usia, pekerjaan, pendidikan, bahkan organisasi keagamaan. Pasangan yang tidak sekufu seringkali menjadi pemicu terjadinya perselisihan di antara keduanya. Sebaliknya, pasangan yang sekufu akan sangat membantu proses sosialisasi menuju tercapainya kebahagiaan keluarga, yaitu keluarga yang sakinah, mawaddah dan rahmah.
\end{abstract}

\section{Kata Kunci: Kafa'ah, Hukum Keluarga, Keluarga Sakinah}

\begin{abstract}
Islam shows great concern for the welfare of the family. In forming a family, prior to marriage, the prospective husband and wife should know each other's partners. Harmony and balance between partners is needed in navigating the household ark. This can be done from the apprenticeship stage, which is when a person determines who is worthy of being his life companion. Harmony and balance in Islam is known as kufu 'or kafa'ah. In this modern era, it is not uncommon for us to find domestic problems that are caused by a striking difference between the two various things, both in terms of religion, race, social status, and so on. The criteria for kufu' in Islam basically only include the factors of wealth, heredity, beauty and religion. However, over time, this concept has developed into several factors such as age, occupation, education, and even religious organizations. Unbalanced couples often lead to disputes between the two. Meanwhile, a balanced couples will greatly assist the socialization process towards family happiness, namely the sakinah, mawaddah and rahmah families.
\end{abstract}

Keywords: Kafa'ah, Family Law, Sakinah Family. 


\section{A. PENDAHULUAN}

Manusia merupakan makhluk biologis yang memiliki hasrat serta minat untuk mengembangkan keturunan sebagai tunas atau generasi penerus yang akan melanjutkan garis keturunannya. ${ }^{1}$ Pada dasarnya manusia diciptakan oleh Allah Swt. hidup secara berpasang-pasangan dari jenis kelamin laki-laki dan perempuan yang diikat oleh sebuah perkawinan. ${ }^{2}$

Perkawinan merupakan salah satu jalan Islam dalam memuliakan ummatnya. Perkawinan merupakan awal mula terbentuknya sebuah keluarga, sehingga perkawinan sangat dianjurkan oleh Islam bagi yang telah mempunyai kemampuan dan kesiapan untuk menjalaninya. Islam mengatur tatacara untuk memulai perkawinan, salah satunya dengan cara meminang terlebih dahulu. Peminangan ini bertujuan untuk mengetahui apakah calon suami dan calon istri mempunyai tingkatan keseimbangan atau dalam bahasa Arab sering disebut dengan kafa'ah atau biasa dikenal masyarakat dengan kata sekufu.

Tinjauan kafa'ah ini selalu dilakukan agar perkawinan dapat dilakukan secara baik dan dapat bertahan selamanya. Hal ini dianggap penting agar masing-masing dapat memahami dan mengerti kepribadian calon pasangan yang tentu berbeda. Jika pasangan tidak dapat menemukan keseimbangan dan kesamaan satu sama lain, maka kebersamaan yang berlangsung lama akan menimbulkan kebosanan. Oleh karena itu sebelum akad hendaknya kedua calon pasangan harus meyakini persepsi atas pengenalannya satu sama lain.

Kebiasaan yang terjadi dalam menilai kafa'ah ini dalam praktek masyarakat di Indonesia sangat relatif, karena dasar dan pedoman peninjauan yang digunakan bukan berdasarkan hukum Islam. Namun pada prakteknya, di era modern ini yang menjadi dasar pedomannya adalah pertimbangan hukum adab kebiasaan masyarakat setempat.

\section{B. METODE PENELITIAN}

1 M. Al-Fatih Suryadilaga, Membina Keluarga Mawaddah Warahmah Dalam Bingkai Sunnah Nabi (Yogyakarta: PSW IAIN dan f.f, 2003), hlm. 4.

${ }^{2}$ Rahmat Hakim, Hukum Pernikahan Islam: Untuk IAIN, STAIN, PTAIS (Bandung: Pustaka Setia, 2000), hlm. 17. 
Pendekatan yang digunakan dalam penelitian ini adalah pendekatan yuridis normatif (normative juridical approach). Penelitian ini mengkaji beberapa data sekunder, termasuk bahan-bahan hukum sekunder baik itu peraturan perundangundangan maupun norma-norma positif lain yang mengatur masalah kesetaraan dalam pernikahan. Penelitian ini juga termasuk penelitian kepustakaan yaitu penelitian terhadap data sekunder. ${ }^{3}$

Data data sekunder yang digunakan antara lain peraturan perundangundangan yaitu UU Perkawinan, Kompilasi Hukum Islam, dan Kitab UndangUndang Hukum Perdata yang didukung beberapa bahan buku bacaan dan jurnal yang secara umum maupun spesifik membahas permasalahan kesetaraan dalam perkawinan ini. Penelitian ini menggunakan metode analisis deskriptif kualitatif, yaitu mengambil suatu penilaian secara tidak langsung dengan cara menarik kesimpulan yang dituangkan dalam bentuk pernyataan atau tulisan. ${ }^{4}$

\section{PEMBAHASAN}

\section{Konsep Sekufu dan Kriterianya Dalam Islam}

Sekufu berarti memiliki kafa'ah. Secara etimologi kafa'ah berarti sama, sederajat, sepadan atau sebanding. ${ }^{5}$ Dalam kamus bahasa Arab kafa'ah berasal dari kata كفاء - كفاءة yang berarti kesamaan, sepadan dan sejodoh. ${ }^{6}$ Sedangkan dalam kamus lengkap Bahasa Indonesia, kafa'ah berarti seimbang. ${ }^{7}$ Sementara Ensiklopedi Islam dan Kamus Fiqih Islam memiliki kesamaan dalam mendefinisikan kafa'ah atau kufu', yakni memiliki arti sebanding, setaraf, seimbang, keserasian atau kesesuaian. ${ }^{8}$

Maksud kafa'ah dalam bab perkawinan ini yaitu laki-laki sebanding dengan perempuan, sama dalam kedudukan, sebanding dalam tingkat sosialnya, dan sederajat dalam akhlak serta kekayaannya. Adanya kafa'ah ini dalam kehidupan

\footnotetext{
${ }^{3}$ Soerjono Soekanto dan Sri Mamudji, Penelitian Hukum Normatif, Suatu Tinjauan Singkat (Jakarta: Rajawali, 1985), hlm. 15.

${ }^{4}$ Lexy J. Moleong, Metode Penelitian Kualitatif (Bandung: Remaja Rosda Karya, 2011), hlm. 248

${ }^{5}$ Sayyid Sabiq, Fikih Sunnah, Jilid 7 (Bandung: PT. Al-Ma’arif, 1997), hlm. 36.

${ }^{6}$ Mahmud Yunus, Kamus Arab Indonesia (Jakarta: Hidakarya Agung, 1990), hlm. 378.

${ }^{7}$ Tri Rama K, Kamus Lengkap Bahasa Indonesia (Surabaya: Karya Agung, t.th), hlm. 218.

8 Dewan Redaksi Ensiklopedi Islam, Ensiklopedi Islam, (Jakarta: PT. Ichtiar Baru Van Hoeve, 1994), hlm. 845.
} 
suami istri tidak diragukan lagi akan bisa lebih menjamin kebahagiaan pernikahan dan lebih menjaga dari kegagalan dan kegoncangan rumah tangga. ${ }^{9}$

Al-Qur'an juga menyebutkan kata yang berakar kafa'ah seperti berikut.

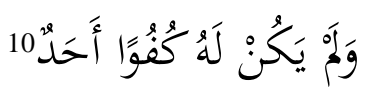

"Dan tidak ada seorangpun yang setara dengan Dia".

Muhammad Abu Zahrah mendefinisikan kafa'ah dengan keseimbangan antara calon suami dan calon istri dengan keadaan tertentu, yang dengan keadaan tersebut keduanya akan bisa menghindari kesusahan dalam menjalani kehidupan rumah tangga. ${ }^{11}$

Kafa'ah menurut Madzhab Syafi'i merupakan hal penting yang harus diperhatikan sebelum perkawinan. Keberadaan kafa'ah diyakini sebagai faktor yang dapat menghilangkan dan menghindarkan munculnya aib dalam keluarga. $K a f a$ 'ah adalah suatu upaya untuk mencari persamaan antara suami dan istri baik dalam kesempurnaan maupun keadaan selain bebas dari cacat. ${ }^{12}$ Adapun persamaan yang dimaksud adalah kondisi suami yang setara dengan istrinya dalam kedudukan sosial, agama, moral (akhlaq) dan ekonomi. ${ }^{13}$ Dengan demikian sebagian masyarakat meyakini bahwa kesepadanan antara suami dan istri menjadi salah satu faktor keharmonisan dalam rumah tangga.

Selain sebagai syarat, kafa'ah juga berkedudukan sebagai objek pertimbangan perkawinan. Disini kafa'ah lebih dipahami sebagai bentuk dan macam-macamnya atau kriteria tertentu yang dijadikan seseorang untuk melihat pasangannya. Kedudukan ini memungkinkan kafa 'ah dijadikan standar pilihan dan alasan bagi seseorang untuk memilih dan menerima/menolak pasangannya. Di sisi lain, kafa'ah juga berfungsi sebagai cermin seseorang untuk menentukan pasangannya. Berdasarkan pengertian kafa'ah yang berarti sepadan atau sama antara laki-laki dan perempuan, maka sesungguhnya kafa'ah memiliki peran

${ }^{9}$ Sabiq, Fikih Sunnah, hlm. 36.

${ }^{10}$ Qs. Al-Ikhlas (112): 4.

11 Muhammad Abu Zahrah, Al-Ahwal Asy-Syakhsiyyah (Mesir: Dar al-Fikr wa al-Arabi, 1950), hlm. 156.

12 'Abd al-Rahman al-Jazairi, Kitab al-Fiqh al-Mazahib al-Arba'ah, Jilid IV, Cet. I (Beirut: Dar al Kutub al-'Ilmiyah, 1990), hlm. 57.

${ }^{13}$ Mufidah Ch, Psikologi Keluarga Islam Berwawasan Gender, Cet. III (Malang: UIN Maliki Press, 2013), hlm. 77. 
sebagai cermin agar seseorang yang menentukan pasangannya, baik itu memilih atau menerima/menolak bisa melihat dirinya sendiri terlebih dahulu sebelum melihat pasangannya. ${ }^{14}$

Dalam memilih pasangan, Rasulullah Saw. memberikan tuntunan bahwa ada empat kriteria sekufu yang secara sosial selalu diperhatikan pada calon pasangan yang akan dipilih, sebagaimana hadits berikut.

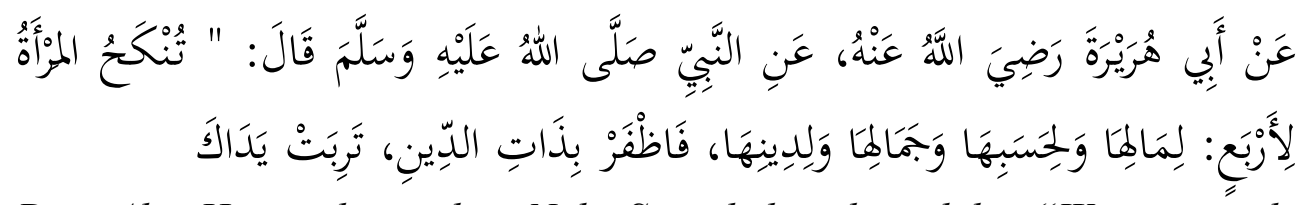

Dari Abu Hurairah r.a dari Nabi Saw, beliau bersabda: "Wanita itu dinikahi karena empat pertimbangan, kekayaannya, nasabnya, kecantikannya dan agamanya. Pilihlah wanita yang beragama maka kalian akan beruntung." HR. Bukhari.

Menurut hadits tersebut, kriteria sekufu meliputi faktor harta, keturunan, kecantikan dan agama. Berikut penjelasannya.

\section{a. Faktor Harta}

Seseorang yang akan menikah hendaknya mempertimbangkan faktor harta dari calon suami atau calon isterinya, karena harta merupakan kebutuhan primer dan sekunder manusia. Nilai harta tidak terletak pada jumlahnya namun pada dari mana dan untuk apa. Jika orang itu memperoleh harta banyak dari usahanya yang halal, maka itu adalah karunia Allah. Kemudian jika harta yang banyak itu digunakan untuk membuat kemaslahatan sebanyak-banyaknya bagi keluarga, masyarakat, dan bangsa, maka itu adalah sebesar-besar ibadah. ${ }^{15}$ Dengan demikian ketika seseorang berobsesi terhadap harta di jalan kebaikan maka hal itu dapat bernilai ibadah.

Namun, condong kepada harta bahkan berharap kebahagiaan melalui harta bukan merupakan tujuan dari menikah. Harta bisa berkurang bahkan bisa hilang dalam waktu tertentu. Dengan demikian harta bukan faktor utama untuk menjadi pertimbangan seseorang yang akan menikah.

\footnotetext{
${ }^{14}$ Ibrahim Al Hakim, Prioritas Kafa'ah Bagi Orang-Orang Yang Terlambat Menikah, Tesis (Surabaya: UIN Sunan Ampel, 2018), hlm. 35.

${ }^{15}$ Ahmad Mubarok, Psikologi Keluarga (Malang: Madani, 2016), hlm. 99.
} 


\section{b. Faktor Keturunan}

Rasulullah Saw. pernah menikahkan Zainab yang berketurunan bangsawan dengan Zaid bin Haritsah seorang hamba sahaya. Beliau juga pernah menikahkan Miqdad seorang berstatus sosial rendah dengan seorang perempuan bernama Dzaba'ah binti Zubair bin Abdul Muthalib yang berstatus sosial tinggi. ${ }^{16}$ Selanjutnya hal ini diikuti oleh sahabat beliau, Hudzaifah yang menikahkan Salim seorang bekas hamba sahaya dengan Hindun binti Al-Walid bi Utbah bin Rabi'ah. Berdasarkan hal tersebut, Rasulullah melakukan pembongkaran budaya patriarki yang menganut bahwa perempuan yang berstatus sosial tinggi akan menjadi turun derajatnya di masyarakat ketika menikah dengan seorang laki-laki yang berstatus lebih rendah. Hal ini juga ditegaskan dalam hadits beliau sebagai berikut.

"Diriwayatkan dari Abi Burdah dari Abi Musa ra dia berkata, bahwa Rasul Saw telah bersabda bahwa barangsiapa yang memiliki seorang budak dan ia berbuat baik kepadanya lalu memerdekakannya atau bahkan menikahinya maka orang tersebut mendapatkan pahala yang berlipat." ${ }^{17}$

Faktor keturunan ini merupakan salah satu faktor yang dapat mempengaruhi pribadi seseorang. Dalam proses menuju pernikahan, faktor keturunan ini juga perlu diperhatikan, Genetika orang tua sangat dominan dalam membentuk manusia, bukan saja rupa fisiknya tetapi juga karakteristik kejiwaannya. Hal ini sebagaimana dikatakan pula oleh Nabi Saw. "fainna al- 'iraqa dassas" bahwa darah itu menurun. Keutamaan keturunan bukan bukan pada darah kebangsawanan atau bukan, tetapi lebih pada darah karakter. ${ }^{18}$

\section{c. Faktor Kecantikan}

Manusia diciptakan Tuhan juga sebagai makhluk yang terindah (fii ahsani taqwiim), baik secara fisik maupun psikologis. Oleh karena itu manusia didesain untuk mengerti keindahan dan bisa menikmati keindahan. Sudah menjadi sunnatullah, lelaki tertarik pada perempuan cantik, dan sebaliknya, tetapi selera kecantikan berbeda-beda setiap orang. Ada yang lebih tertarik kepada kecantikan

\footnotetext{
${ }^{16}$ Sayyid Sabiq, Fiqh Sunnah, Jilid 3 (Beirut: Dar Al-Fikr, 1983), hlm. 126.

${ }^{17}$ Muhammadi bin Ismail Abu Abdillah Al-Bukhari Al-Jafiy, Shahih Bukhari Juz 2 (Beirut: Dar Ibn Katsir, t.th), hlm. 899.

${ }^{18}$ Mubarok, Psikologi Keluarga, hlm. 102.
} 
lahir, ada yang lebih tertarik kepada kecantikan budi pekerti. ${ }^{19}$ Dengan demikian Islam telah menganjurkan tidak memilih kecantikan atau kegagahan sebagai pertimbangan yang utama dalam memilih pasangan.

\section{d. Faktor Agama}

Pada hadits sebelumnya disebutkan bahwa faktor terakhir yang perlu dipertimbangkan adalah faktor agama, maka kalian akan beruntung. Bidzatiddin pada hadits tersebut mengandung arti substansi atau sifat. Perempuan atau laki-laki yang bidzatiddin adalah orang yang beragama secara substansial atau dapat dilihat sifat-sifatnya sebagai orang yang mematuhi agama. Selain itu secara horizontal memaksimalkan dirinya memberikan kemanfaatan maksimal kepada manusia dan makhluk lain, karena manusia tak lain adalah pengejawantahan kasih sayang Tuhan. ${ }^{20}$

Jika dilihat dari sisi psikologis, maka ini merupakan kasih sayang Rasulullah kepada kita selaku ummatnya untuk dapat bebas memilih calon pasangan. Adapun alasan faktor harta ditempatkan yang pertama agar kita masih dapat memilih mana yang sesuai dengan keinginan kita dan berhak menolak jika tidak sesuai. Begitu juga dengan faktor keturunan dan faktor kecantikan. Setiap orang bebas memilih dengan keturunan seperti apa ia akan hidup berdampingan, dan orang setampan atau secantik apa orang yang akan menemani hidupnya hingga masa tua nanti. Namun tidak demikian perihal agama, hal ini disebabkan karena agama adalah sepenuhnya menjadi hak Allah. Suatu perkawinan yang tidak memperhatikan masalah agama maka perkawinan tersebut tidak sah.

Dengan demikian, maka kafa'ah menjadi pertimbangan khusus dengan kriteria yang khusus. Kafa 'ah juga dapat disesuaikan dengan kondisi dan kebutuhan suami istri, serta kemaslahatan bersama. Sebagian besar pendapat ulama menegaskan bahwa kafa'ah dilakukan dengan pertimbangan agama atau akhlaq alkarimah, sedangkan untuk kafa'ah dari aspek kekayaan, kecantikan atau ketampanan, harta benda, kedudukan, atau jabatan maupun status sosial bukan menjadi pertimbangan mutlak. ${ }^{21} \mathrm{Hal}$ ini didasari oleh ayat berikut.

\footnotetext{
${ }^{19}$ Ibid, hlm. 104.

${ }^{20}$ Ibid, hlm. 105.

${ }^{21}$ Mufidah, Psikologi Keluarga Islam, hlm.78.
} 


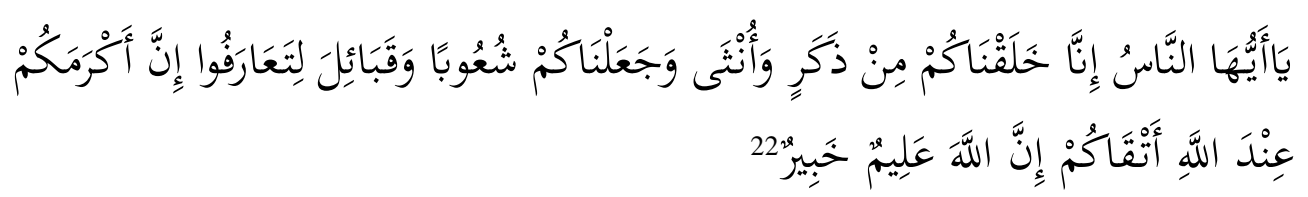

"Hai manusia, sesunnguhnya Kami menciptakan kamu dari seorang laki-laki dan perempuan dan menjadikan kamu berbangsa-bangsa dan bersuku-suku supaya kamu saling mengenal. Sesungguhnya orang yang paling mulia diantara kamu disisi Allah ialah orang yang paling takwa diantara kamu. Sesungguhnya Allah Maha Mengetahui lagi Maha Mengenal.”

Menurut ayat tersebut, kafa'ah dipandang kondisional dan relatif. Hal ini karena manusia merupakan makhluk yang diciptakan Allah dengan sangat beragam, mulai dari bentuk wajah, warna kulit, ras, suku, budaya, serta bahasa. Dengan demikian adanya perkawinan diharapkan akan mempertemukan serta menyatukan segala perbedaan yang ada diantara dua insan.

Lebih lanjut dalam menetapkan kriteria sekufu ini, para ulama berbeda pendapat sebagai berikut. $^{23}$

a. Madzhab Hanafi mengatakan bahwa kafa 'ah meliputi lima hal ,yaitu:

1. Keturunan (an-nasab) dalam kaitan ini terutama Arab dan non Arab,

2. Harta,

3. Profesi (al-hirfa'),

4. Merdeka (al-hurriyah),

5. Agama atau kepercayaan (ad-diyanah).

b. Madzhab Malikiyah menghubungkan kafa'ah hanya dengan satu hal yakni beragama, dalam artian muslim yang tidak fasik dan sehat fisiknya dalam pengertian bebas dari cacat seperti belang, gila dan lain-lain. Sedangkan harta, nasab dan status kemerdekaan itu merupakan kafa'ah yang tidak menjadi prasyarat utama bagi suatu pernikahan.

c. Madzhab Syafi'iyah, kafa'ah meliputi empat hal, yakni:

1. Nasab,

2. Agama (ad-diniyah),

3. Merdeka

${ }^{22}$ Qs. Al-Hujurat (49): 13

${ }^{23}$ Muhammad Amin Suma, Hukum Keluarga Islam di Dunia Islam (Jakarta: Raja Grafindo Persada, 2004), hlm. 83 
TAHKIM, Jurnal Peradaban dan Hukum Islam. Vol.4 No.1 (Maret, 2021) | ISSN : 2597-7962

4. Status sosial terutama pekerjaannya (ekonomi).

d. Madzhab Hanabilah, kafa'ah meliputi lima hal, yaitu:

1. Agama (ad-diniyah) dalam konteksnya yang sangat luas,

2. Status sosial terutama profesi,

3. Kemampuan finansial terutama dihubungkan dengan hal-hal yang wajib dibayar seperti mas kawin (mahar) dan uang belanja (biaya hidup, nafkah),

4. Merdeka (al-hurriyah),

5. Nasab dalam kaitannya antara arab dan non arab ('Ajam)

Sedangkan Ibnu Hazm berpendapat bahwa tidak ada ukuran kesepadanan atas $k a f a$ 'ah dalam perkawinan. Beliau hanya menekankan masalah pernikahan laki-laki baik dengan perempuan pezina atau sebaliknya perempuan baik dengan laki-laki pezina. ${ }^{24} \mathrm{Hal}$ ini didasarkan oleh ayat berikut.

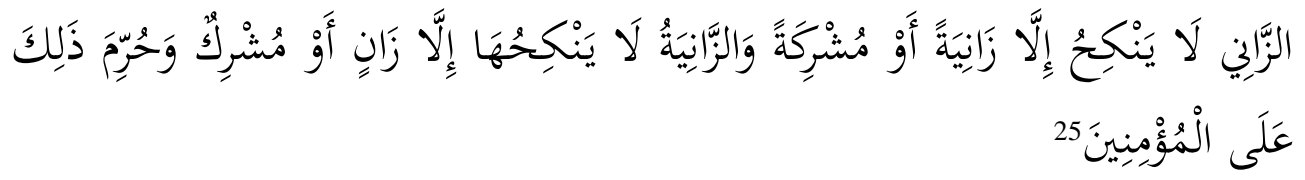

“Laki-laki yang berzina tidak mengawini melainkan perempuan yang berzina atau perempuan yang musyrik. Dan perempuan yang berzina tidak dikawini melainkan oleh laki-laki yang berzina atau laki-laki musyrik. Dan yang demikan itu diharamkan atas orang-orang yang mukmin."

Di samping itu, dalam tradisi orang Jawa dalam memilih pasangan biasanya menggunakan standar bobot, bibit, bebet. Bobot yaitu suatu tinjauan untuk memilih jodoh dari segi harta (kekayaan) dan status sosialnya. Bibit adalah suatu tinjauan dari segi nasab (keturunan) dan bebet merupakan tinjauan dari segi akhlaknya. ${ }^{26}$

\section{Konsep Sekufu dalam Peraturan Perundang-Undangan}

Objek kafa'ah tiada lain adalah laki-laki dan perempuan yang akan melangsungkan pernikahan, maka segala sesuatu yang berkaitan dengan kafa'ah menjadi perhatian perempuan dan walinya. Ulama fiqh saat itu menjadikan kafa'ah dalam perkawinan sebagai syarat lazim, bukan sebagai syarat sahnya perkawinan.

${ }^{24}$ Ibid

${ }^{25}$ Qs. Al-Nur (24): 3

${ }^{26}$ Ainul Ruslan, “Konsep Kafa'ah Dalam Perkawinan Menurut Ibn Hazm Dan Imam Syafi'i, Skripsi (Malang: Universitas Muhammadiyyah Malang, 2016), hlm. 5. 
Namun seiring dengan pesatnya perubahan sosial dalam masyarakat, orang tidak lagi memperhatikan dari bangsa mana ia datang dan berasal, maka yang menjadi perhatian kini adalah adat dan kebiasaan yakni masalah finansial (money oriented). ${ }^{27}$ Hal inilah yang menjadi salah satu penyebab banyaknya perkawinan beda agama. Padahal ukuran utama kafa'ah adalah agama.

Dalam Kompilasi Hukum Islam, kafa'ah juga diatur dalam Pasal 61 yang menyebutkan bahwa tidak sekufu tidak dapat dijadikan alasan untuk mencegah perkawinan, kecuali tidak sekufu karena perbedaan agama atau ikhtilaafu al dien. ${ }^{28}$ Oleh karena itu, maka yang dimaksud kafa'ah hanyalah agama, selain itu bukan. Namun sampai saat ini syarat sekufu hanya terbatas syarat lazim saja, tidak termasuk syarat sah dalam perkawinan.

Dalam UU No.16 Tahun 2019 Tentang Perubahan Atas UU No.1 Tahun 1974 ditetapkan bahwa perkawinan hanya diizinkan apabila pria dan wanita sudah mencapai umur 19 (sembilan belas) tahun. ${ }^{29}$ Dengan demikian, calon suami dan istri yang belum mencapai usia tersebut dilarang melangsungkan pernikahan, kecuali dengan keadaaan mendesak. Namun pembatasan ini hanya sekedar syarat dibolehkannya seseorang untuk menikah, bukan berarti calon suami dan istri harus memiliki usia yang sama.

Selain Indonesia, beberapa negara muslim juga memperhatikan masalah kafa'ah ini. Di Suria, pada tahun 1953 diberlakukan undang-undang yang disebut Syiria Law on Personal Status, yang mengatur tentang perkawinan dan kewarisan. Pada pasal 26 dinyatakan bahwa syarat lazim dalam pernikahan itu adalah laki-laki dan perempuan haruslah sekufu. Dengan demikian, Suria menjadikan sekufu sebagai syarat lazim dalam pernikahan. Selanjutnya dalam pasal 27 dinyatakan bahwa apabila perempuan dewasa menikahkan dirinya sendiri tanpa persetujuan walinya, sedang suaminya dianggap tidak sekufu maka walinya bisa mem-fasakh nikahnya. Di Maroko. Hal ini menunjukkan bahwa wali mempunyai hak yang sama, sehingga jika ia anggap pernikahan itu tidak sekufu, maka ia dapat

${ }^{27}$ Nurcahaya, Kafa'ah dalam Perspektif Fiqh Islam dan Undang-Undang Negara Muslim, Jurnal Al-Muqaranah UIN Sumatera Utara Vol. 5 No.1 (2017), hlm. 71-72.

${ }^{28}$ Departemen Agama RI, Kompilasi Hukum Islam (Jakarta: Direktorat Jenderal Pembinaan Kelembagaan Agama Islam, 1998), hlm. 33.

${ }^{29}$ UU No. 16 Tahun 2019, Pasal 7 
membatalkan pernikahan tersebut. Kemudian dalam pasal 30 dinyatakan bahwa yang mempunyai hak bukan saja si anak perempuan, tapi juga walinya. Undangundang ini juga mengatur masa berlaku kafa'ah hanya pada saat akan dilakukan akad, dan tidak berpengaruh setelah akad nikah dilangsungkan. ${ }^{30}$

Di samping itu, Libanon menggunakan The Ottoman Law of Family Right pada tahun 1917 sebagai undang-undang hukum keluarga. Pasal 45 undang-undang ini menyebutkan bahwa seorang laki-laki haruslah sepadan dengan seorang perempuan dalam hal kekayaan, pekerjaan (jabatan) dan derajat. Sederajat dalam kekayaan berarti bahwa seorang suami hendaklah mempunyai kemampuan untuk membayar mahar, dan mempunyai kemampuan untuk memberi nafkah kepada isterinya. Sederajat dalam pekerjaan berarti bahwa usaha atau pekerjaan suami haruslah sebanding dengan wali isterinya. Sedangkan pada pasal 46 disebutkan bahwa harus sederajat dalam hal akhlak, hal ini terlihat ketika akan melangsungkan perkawinan, maka perubahan itu tidak akan punya pengaruh. Kemudian pada pasal 50 disebutkan bahwa pengadilan dapat membatalkan perkawinan yang tidak sekufu, asalkan belum terjadi kehamilan. ${ }^{31}$

Selanjutnya di Jordan Pada tahun 1951 diberlakukan hukum keluarga yang disebut dengan Jordanian Law of Family Rights yang mengatur tentang perkawinan, kewarisan dan wakaf. Pada pasal 27 disebutkan bahwa jika suami tidak sekufu dengan istrinya, maka hakim boleh memutuskan perkawinan, hal ini dapat dilakukan sebelum istrinya hamil. Di dua negeri ini -Libanon dan Jordan- kafa'ah sudah beranjak menjadi syarat sah perkawinan. Terlihat dari seorang hakim boleh memutuskan perkawinan jika dianggap perkawinan itu tidak sekufu, asalkan istrinya belum hamil. Dengan demikian dapat disimpulkan bahwa undang-undang hukum keluarga di dua negeri ini sedikit lebih ketat memberlakukan kafa'ah dalam perkawinan. ${ }^{32}$ Pada tahun 1976, Jordan juga memberlakukan undang-undang hukum keluarga yang disebut dengan Cede of Personal Status. Dalam pasal 20 disebutkan bahwa diharuskan bagi seorang laki-laki yang akan melangsungkan

${ }^{30}$ Tahir Mahmood, Family Law Reform in The Muslim World (New Delhi: The Indian Law Institute, 1972), hlm. 93.

${ }^{31}$ Ibid, hlm. 41.

${ }^{32}$ Ibid, hlm. 81. 
perkawinan haruslah sederajat secara finansial. Hal ini bertujuan akan menjadi ukuran mengenai kemampuan seseorang untuk membayar mahar dan kemampuannya untuk memberi nafkah. ${ }^{33}$

Selain itu, Maroko dalam Moroccan Code of Personal Status pada tahun 1958 pasal 14 (a) disebutkan bahwa hanya perempuan dan walinya yang dapat membatalkan suatu pernikahan atas dasar tidak sekufu dengan suaminya. Sedangkan pada poin (b) disebutkan bahwa kafa'ah itu dapat dinilai pada saat pernikahan dan dapat dipastikan berdasarkan adat kebiasaan. Sementara pasal 15 hanya perempuan itu saja yang mengetahui bahwa adanya perbedaan dalam hal usia dengan laki-laki yang akan menjadi suaminya. ${ }^{34}$ Dari keempat negara tersebut maka dapat dilihat bahwa beberapa sebagian negara seperti Jordan dan Libanon menjadikan kafa'ah bukan hanya menjadi syarat lazim, tapi juga menjadikannya sebagai syarat sahnya pernikahan. Sementara, Suria dan Marokko masih menjadikan kafa'ah sebagai syarat lazim dalam pernikahan sama seperti Indonesia.

\section{Konsep Sekufu Modern}

\section{a. Sekufu dalam Usia}

Usia ideal dalam perkawinan bisa dilihat pada kisaran batas usia minimal dan batas usia maksimal serta jarak usia antara kedua calon mempelai dengan pertimbangan psikologis dan kesehatan. Menikah yang tidak dilandasi dengan usia yang matang, maka akan rentan timbul konflik dan masalah berkepanjangan. Hal itu disebabkan oleh kondisi psikis dan pola pikir yang masih belum siap menerima tanggung jawab sedemikian besar dalam rumah tangga. Oleh karena itu, tidak heran jika banyak kasus-kasus perceraian yang terjadi disebabkan oleh kawin usia muda. ${ }^{35}$

Menurut disiplin ilmu psikologi, usia remaja dikatakan belum siap untuk melangsungkan pernikahan yang di dalamnya terdapat berbagai permasalahan dan rintangan. Menurut Edi Nur Hasmi, psikolog yang juga Direktur Remaja dan Kesehatan Reproduksi BKKBN, bahwa di masa remaja mental dan emosi bisa

${ }^{33}$ Tahir Mahmood, Personal Law in Islamic Countries (New Delhi: Academy of Law and Religion, 1987), hlm. 81.

${ }^{34}$ Ibid

${ }^{35}$ Al-Hakim, Prioritas Kafa'ah, hlm. 51. 
dikatakan belum stabil. Kestabilan emosi umumnya terjadi pada usia 24 tahun, sebab pada usia ini biasanya mulai timbul transisi dari gejolak remaja ke masa dewasa yang stabil. Sedangkan persiapan mental untuk menikah mengandung pengertian sebagai kondisi psikologis emosional untuk menanggung berbagai resiko yang timbul selama hidup dalam pernikahan, misalnya pembiayaan ekonomi keluarga, memelihara dan mendidik anak-anak, membiayai kesehatan secara mutlak dalam keluarganya. Sementara kesiapan mental seseorang erat kaitannya dengan unsur usia, pendidikan dan status karier/pekerjaan pada umumnya. ${ }^{36}$

Usia juga menjadi faktor penting dalam seleksi calon pasangan. Jarak usia antara laki-laki dan perempuan tidak jarang pula dijadikan pertimbangan. Bilamana jarak usia terlampau jauh, maka hal itu seringkali dianggap tidak wajar oleh masyarakat. IDN Times merangkum pernikahan beda usia jauh yang terjadi sepanjang tahun 2017 dan sempat menggemparkan masyarakat, diantaranya yaitu: (1) Selamet Royadi 16 tahun dengan Nenek Rohaya 71 tahun di Sumatera Selatan; (2) Sofiyan Loho Dandel 28 tahun dengan Martha Potu 82 tahun di Minahasa; (3) Andi Darfan 24 tahun dengan Andi Rosmiati Untung 55 tahun di Sulawesi Selatan; (4) Rokim 24 tahun dan Tampi 67 tahun di Madiun, dan; (5) Ade Irawan 25 tahun dan Manih 67 tahun di Bogor. ${ }^{37}$

Jarak usia antara laki-laki dan perempuan saat menikah memang selalu menjadi pertimbangan. Pada era modern ini, mayoritas perempuan menginginkan pasangan laki-laki yang lebih dewasa, dalam hal ini usianya lebih tua. Begitu juga dengan laki-laki, mayoritas mereka menginginkan pasangan perempuannya lebih muda atau usianya di bawah umur si laki-laki. Mungkin jika jarak tidak terlalu jauh, perbedaan usia ini tidak akan menjadi masalah. Bahkan walaupun si perempuan lebih tua daripada laki-laki, jika jarak usia tidak terlampau jauh maka itu juga tidak menjadi masalah dan perhatian di masyarakat.

Islam dalam hal ini tidak mengatur secara tegas berapa jarak usia ideal antara laki-laki dengan perempuan, karena Nabi sendiri menikahi Khadijah binti Khuwailid yang berusia 40 tahun dan berjarak 15 tahun lebih muda Rasulullah Saw

\footnotetext{
${ }^{36}$ Agus Dariyo, Psikologi Perkembangan Dewasa Muda (Jakarta: Gramedia Widya Sarana Indonesia, 2003), hlm. 157.

${ }^{37}$ Al- Hakim, Prioritas Kafa'ah., hlm. 61.
} 
yang berusia 25 tahun. Begitu pula pernikahan beliau dengan 'Aisyah binti Abu Bakr al-Siddiq yang berjarak 49 tahun dimana Rasulullah Saw berusia 55 tahun dan Aisyah berusia 6 tahun. Hal ini menunjukkan bahwa usia hanyalah angka yang tidak lebih utama daripada kedewasaan yang dilandasi dengan cinta dan kasih sayang untuk membina rumah tangga.

Di samping itu, UU No.16 Tahun 2019 Tentang Perubahan Atas UU No.1 Tahun 1974 Tentang Perkawinan menetapkan batas usia minimal perkawinan yang sama bagi laki-laki dan perempuan yakni 19 tahun. Berdasarkan naskah akademiknya, UU ini dibentuk berdasarkan asas persamaan (kesetaraan dan keadilan), asas non diskriminasi dan prinsip kepentingan terbaik bagi anak. ${ }^{38} \mathrm{Hal}$ ini membuktikan bahwa sekufu dalam usia pada konteks modern ini sudah menjadi sorotan sebagai objek pertimbangan. Namun pembatasan ini hanya sekedar batas dibolehkannya seseorang untuk melangsungkan pernikahan, bukan berarti kedua calon mempelai harus berada di usia yang sama. Pembatasan usia ini bertujuan agar masyarakat dapat lebih mempersiapkan mental calon pasangan yang akan menikah dengan memperhatikan berbagai aspek. Adapun sebaiknya kedua mempelai tidak terlampau jauh jarak usia satu dengan yang lain guna mewujudkan komunikasi dan relasi yang baik antara suami istri.

\section{b. Sekufu dalam Pekerjaan}

Unsur lain yang terdapat dalam kafa'ah dalam konteks modern yaitu pekerjaan atau mata pencaharian. Pekerjaan berkenaan dengan segala sarana maupun prasarana yang dapat dijadikan sumber penghidupan baik perusahaan maupun yang lainnya. ${ }^{39}$

Jadi apabila ada seorang wanita yang berasal dari kalangan orang yang mempunyai pekerjaan tetap dan terhormat, maka dianggap tidak sekufu' dengan orang yang rendah penghasilannya. Pendapat lain mengatakan bahwa dalam pemberlakuan segi pekerjaan ini harus diperhatikan 'urf (adat) dan tradisi yang berlaku pada suatu tempat. Suatu pekerjaan dianggap terhormat atau tidaknya

38 Kementerian Hukum dan Hak Asasi Manusia, Hasil Penyelarasan Naskah Akademik Rancangan Undang-Undang Tentang Perubahan Atas Undang-Undang No 1 Tahun 1974 Tentang Perkawinan (Jakarta: Badan Pembinaan Hukum Nasional, 2019), hlm. 9-11.

${ }^{39}$ Al-Hakim, Prioritas Kafa'ah., hlm. 46. 
adalah tergantung pada pandangan adat setempat atau zaman tertentu. ${ }^{40}$ Dengan demikian jika pekerjaan yang disuatu tempat dipandang terhormat tapi di tempat si wanita dianggap rendah, maka pekerjaan tersebut dapat menghalangi terjadinya kafa'ah.

\section{c. Sekufu dalam Pendidikan}

Tingkat pendidikan seseorang dianggap sebagai kriteria kafa 'ah baru pada era modern yang tidak disinggung sama sekali oleh ulama salaf. Saat ini, pendidikan dianggap lebih penting karena tidak hanya melahirkan keterampilan kerja melainkan juga melahirkan perubahan mental, selera, minat, tujuan, dan cara berbicara. $^{41}$

Penelitian Noryamin Aini menunjukkan hasil yang menarik yaitu hanya 9,7\% laki-laki menikahi pasangan yang berpendidikan lebih tinggi darinya (marry up). Sebaliknya, perempuan sangat langka menikah dengan laki-laki yang berpendidikan lebih rendah (marry down). ${ }^{42}$ Artinya, rata-rata seorang laki-laki lebih memilih istri yang pendidikannya lebih rendah karena kesadaran idealisnya, yakni agar superioritas dirinya tidak kalah dengan istrinya.

\section{d. Sekufu dalam Organisasi Keagamaan}

Organisasi keagamaan yang ada di Indonesia cukup beragam. Diantara yang terbesar yaitu Nahdatul Ulama atau biasa disebut dengan NU, Muhammadiyyah dan Persatuan Islam atau biasa disebut dengan Persis. Ketiga organisasi ini pada dasarnya sama secara aqidah, yakni termasuk golongan ahlu sunnah wa al-jama 'ah. Namun dalam tata cara berijtihad untuk menetapkan suatu hukum, ketiganya memiliki perbedaan sehingga terlihat sedikit kontras khususnya dalam hal praktek ibadah dan tradisi keagamaan. Hal ini seringkali memicu konflik diantara masyarakat yang cenderung majemuk, terutama perihal prinsip. Bahkan menjadi sangat rawan ketika konflik ini memasuki ranah sebuah kafa'ah dalam sebuah perkawinan. Seakan-akan ketiga ormas itu menjadi 'agama' yang saling berbeda,

${ }^{40}$ Peunoh Daly, Hukum Perkawinan Islam: Suatu Perbandingan dalam Kalangan Ahlus Sunnah dan Negara - Negara Islam (Jakarta: Bulan Bintang, 1988), hlm. 175.

${ }^{41}$ Horton, Paul B. dan Chester L. Hunt, Sosiologi Jilid 2 (Jakarta: Erlangga, 1999), hlm. 7.

${ }^{42}$ Noryamin Aini, Tradisi Mahar di Ranah Lokalitas Umat Islam: Mahar dan Struktur Sosial di Masyarakat Muslim Indonesia, Jurnal Ahkam Vol. XIV No. 1 Januari (2014), hlm. 20. 
dan seolah-olah perkawinan itu menjadi seperti 'perkawinan terlarang antar agama'. Maka seringkali di beberapa daerah menganut prinsip bahwa syarat kafa'ah dalam perkawinan yaitu harus sama dalam satu organisasi keagamaan, seperti yang ditemukan di kabupaten Lamongan dan Malang antara organisasi NU dan Muhammadiyyah.

Tidak hanya dalam organisasi keagamaan, ada juga komunitas LDII yang bahkan sangat tegas menetapkan syarat kafa'ahnya adalah dengan sesama anggota LDII. Mereka memiliki prinsip bahwa pernikahan anggota LDII hendaknya dilakukan dengan sesama anggota LDII, hal ini sangat dianjurkan bahkan mereka menganggap berhukum fardlu 'ain. Oleh karenanya anjuran ini sangat berhubungan erat dengan pendataan anggota yang siap untuk kawin, dengan tujuan mereka memilih pasanganya dari golongan LDII sendiri. ${ }^{43}$

Adapun salah satu alasan dalam memegang prinsip sekufu dalam satu organisasi keagamaan atau satu golongan ini, sebagian masyarakat meyakini bahwa dengan menikah dengan orang yang berlatar belakang sama dan sepemahaman dalam fiqh maka akan menunjang keharmonisan dalam berumah tangga. Namun pada kenyataannya banyak pula pasangan yang beda organisasi keagamaan namun bisa tetap rukun dan harmonis. Hal ini menunjukkan bahwa kafa' ah dalam konteks organisasi keagamaan juga bersifat relatif.

Berbagai pertimbangan terhadap masalah-masalah tersebut dimaksudkan agar dalam kehidupan berumah tangga tidak terjadi ketimpangan dan ketidakcocokan. Selain itu, secara psikologis seseorang yang mendapat pasangan yang sesuai dengan keinginannya akan sangat membantu dalam proses sosialisasi menuju tercapainya kebahagiaan keluarga, yaitu keluarga yang sakinah mawaddah wa rahmah. Perasaan sreg dan cocok yang dirasakan pasangan akan dapat mendistorsi berbagai kekurangan, sehingga meskipun mereka hidup dalam dalam kesahajaan, tetapi mereka kaya dengan perasaan, sehingga mereka dapat merasa ramai dalam keberduaan, merasa meriah dalam kesunyian malam, merasa ringan dalam memikul beban, merasa sebentar dalam mengarungi perjalanan panjang. ${ }^{44}$

\footnotetext{
${ }^{43}$ Sarifudin Zuhri, Analisis Hukum Islam Terhadap Proses Perjodohan Dan Kriteria Kafa'ah Dalam Perkawinan Anggota LDII, Skripsi (Surabaya: UIN Sunan Ampel, 2018), hlm. 57.

${ }^{44}$ Mubarok, Psikologi Keluarga, hlm. 97.
} 
Hal ini akan berbanding terbalik, posisi suami yang tidak sekufu dengan istrinya ataupun sebaliknya, sering kali memicu perselisihan di antara keduanya. Perselisihan yang terus-menerus, kemudian diiringi dengan kata-kata yang menyakitkan, tindak pemukulan atau penganiayaan fisik, perilaku yang tidak bertanggung jawab, tidak memenuhi kebutuhan ekonomis atau biologis, kawin lagi, bahkan dapat pula menjurus pada tindakan sadisme dengan menyengsarakan atau menghilangkan nyawa. ${ }^{45}$

Dengan demikian, latar belakang diterapkannya konsep kafa'ah dalam pernikahan bertujuan untuk menghindari terjadinya krisis yang dapat melanda kehidupan rumah tangga. Kafa' $a h$ dalam pernikahan dapat mendukung tercapainya tujuan pernikahan. Tujuan pernikahan dapat tercapai apabila kerjasama antara suami dan istri berjalan dengan baik sehingga tercipta suasana damai, aman dan sejahtera. Tercapainya tujuan pernikahan memang tidak mutlak ditentukan oleh faktor kesepadanan semata, tetapi hal tersebut bisa menjadi penunjang yang utama. Namun tetap yang paling penting dan harus selalu diutamakan adalah faktor agama serta akhlak. ${ }^{46}$ Selain itu, kafa'ah merupakan tindakan preventif untuk menghindari perceraian. Bagi pasangan yang menikah namun tidak kafa'ah merupakan hal yang tidak dapat dicegah. Hal ini karena pada dasarnya pernikahan adalah proses penyesuaian diri secara terus menerus antara suami dan isteri, sehingga kafa'ah hanya sebagai salah satu upaya penyesuaian itu. Dengan demikian maka penulis memahami bahwa di era modern ini, kafa'ah sangatlah berpengaruh dalam keharmonisan rumah tangga baik dalam hal kecil maupun besar.

\section{SIMPULAN}

Konsep sekufu yaitu laki-laki sebanding dengan perempuan, sama dalam kedudukan, sebanding dalam tingkat sosialnya, dan sederajat dalam akhlak serta kekayaannya. Sekufu dalam kehidupan suami istri akan lebih menjamin kebahagiaan pernikahan dan lebih menjaga dari kegagalan dan kegoncangan rumah

\footnotetext{
${ }^{45}$ Siti Jahroh, Reinterpretasi Prinsip Kafa 'ah Sebagai Nilai Dasar Dalam Pola Relasi Suami Istri, Jurnal Al-Ahwal UIN Sunan Kalijaga Yogyakarta,Vol. 5 No. 2 (2012), hlm. 59.

${ }^{46}$ M. Fauzil Adhim dan M. Nazif Masykur, Di Ambang Pernikahan (Jakarta: Gema Insani Press, 2002), hlm. 78-82.
} 
tangga. Adapun kriteria sekufu dalam Islam meliputi faktor harta, keturunan, kecantikan, dan agama, namun ukuran utama terletak pada faktor agama.

Konsep sekufu dalam peraturan perundang-undangan di Indonesia diatur dalam pasal 61 Kompilasi hukum Islam, dimana syarat sekufu hanya terbatas syarat lazim saja, tidak termasuk syarat sah dalam perkawinan. Di samping itu beberapa negara muslim seperti Jordan dan Libanon menjadikan kafa'ah bukan hanya menjadi syarat lazim, tapi juga menjadikannya sebagai syarat sahnya pernikahan. Sementara, Suria dan Marokko masih menjadikan kafa'ah sebagai syarat lazim dalam pernikahan sama seperti Indonesia.

Konsep sekufu dalam konteks modern meliputi sekufu dalam usia, sekufu dalam pekerjaan, sekufu dalam pendidikan, dan sekufu dalam organisasi keagamaan. Seseorang yang mendapat pasangan sesuai dengan keinginannya akan sangat membantu dalam proses sosialisasi menuju tercapainya kebahagiaan keluarga, yaitu keluarga yang sakinah mawaddah wa rahmah. Perasaan sreg dan cocok yang dirasakan pasangan akan dapat mendistorsi berbagai kekurangan. Hal ini akan berbanding terbalik, posisi suami yang tidak sekufu dengan istrinya ataupun sebaliknya, sering kali memicu perselisihan di antara keduanya.

\section{DAFTAR PUSTAKA}

Abu Zahrah, Muhammad. (1950). Al-Ahwal Asy-Syakhsiyyah. Mesir: Dar al-Fikr wa al-Arabi.

Adhim, M. Fauzil dan M. Nazif Masykur. (2002). Di Ambang Pernikahan. Jakarta: Gema Insani Press.

Aini, Noryamin. Tradisi Mahar di Ranah Lokalitas Umat Islam: Mahar dan Struktur Sosial di Masyarakat Muslim Indonesia. Jurnal Ahkam Vol. XIV No. 1 Januari 2014.

Al Hakim, Ibrahim. (2018). Prioritas Kafa'ah Bagi Orang-Orang Yang Terlambat Menikah. Tesis. Surabaya: UIN Sunan Ampel.

Al-Jafiy, Muhammad bin Ismail Abu Abdillah Al-Bukhari. (t.th). Shahih Bukhari Juz 2. Beirut: Dar Ibn Katsir.

Al-Jazairi, 'Abd al-Rahman. (1990). Kitab al-Fiqh al-Mazahib al-Arba'ah. Jilid IV. Cet. I. Beirut: Dar al Kutub al-'Ilmiyah.

Ch, Mufidah. (2013). Psikologi Keluarga Islam Berwawasan Gender. Malang: UIN Maliki Press. 
TAHKIM, Jurnal Peradaban dan Hukum Islam. Vol.4 No.l (Maret, 202I) | ISSN : 2597-7962

Daly, Peunoh. (1988). Hukum Perkawinan Islam: Suatu Perbandingan dalam Kalangan Ahlus Sunnah dan Negara - Negara Islam. Jakarta: Bulan Bintang.

Dariyo, Agus. (2003). Psikologi Perkembangan Dewasa Muda. Jakarta: Gramedia Widya Sarana Indonesia.

Departemen Agama RI. (1998). Kompilasi Hukum Islam. Jakarta: Direktorat Jenderal Pembinaan Kelembagaan Agama Islam.

Horton, Paul B. dan Chester L. Hunt. (1999). Sosiologi Jilid 2. Jakarta: Erlangga.

Jahroh, Siti. Reinterpretasi Prinsip Kafa 'ah Sebagai Nilai Dasar Dalam Pola Relasi Suami Istri, Jurnal Al-Ahwal UIN Sunan Kalijaga Vol. 5 No. 2. Yogyakarta. 2012.

K,Tri Rama. (t.th). Kamus Lengkap Bahasa Indonesia. Surabaya: Karya Agung.

Mahmood, Tahir. (1972). Family Law Reform in The Muslim World. New Delhi: The Indian Law Institute.

(1987). Personal Law in Islamic Countries. New Delhi: Academy of Law and Religion.

Mubarok, Ahmad. (2016). Psikologi Keluarga. Malang: Madani.

Nurcahaya, Kafa'ah dalam Perspektif Fiqh Islam dan Undang-Undang Negara Muslim, Jurnal Al-Muqaranah UIN Sumatera Utara Vol. 5 No.1 2017.

Ruslan, Ainul. (2016). Konsep Kafa'ah Dalam Perkawinan Menurut Ibn Hazm Dan Imam Syafi'i. Skripsi. Malang: Universitas Muhammadiyyah Malang.

Sabiq, Sayyid. (1997). Fikih Sunnah. Jilid 7. Bandung: PT. Al-Ma'arif. (1983). Fiqh Sunnah. Jilid 3. Beirut: Dar Al-Fikr.

Suma, Muhammad Amin. (2004) .Hukum keluarga Islam di Dunia Islam. Jakarta: Raja Grafindo Persada.

Yunus, Mahmud. (1990). Kamus Arab Indonesia. Jakarta: Hidakarya Agung.

Zuhri, Sarifudin. (2018). Analisis Hukum Islam Terhadap Proses Perjodohan Dan Kriteria Kafa'ah Dalam Perkawinan Anggota LDII. Skripsi. Surabaya: UIN Sunan Ampel. 
TAHKIM, Jurnal Peradaban dan Hukum Islam. Vol.4 No.1 (Maret, 2021) | ISSN : 2597-7962 